Acta vet. scand. $1964,5,347-361$.

From the Department of Pharmacology and Toxicology, The Royal Veterinary and Agricultural College, Copenhagen.

\title{
DISTRIBUTION OF \\ SULPHONAMIDES IN THE MAMMARY GLAND \\ OF COWS AFTER INTRAMAMMARY AND INTRAVENOUS APPLICATION*)
}

\author{
By \\ Folke Rasmussen
}

In order to attain chemotherapeutic effect, it is necessary that the drug must be introduced into the organism in such a manner that wherever the pathogenic bacteria are found, a sufficient concentration is reached so that they are either killed or can be fought down by the natural defensive reactions of the organism. When intramammary treatment was first introduced in mastitis therapy there was some doubt about the adequacy of the galactogenic dispersion in order to conform with this requirement for rational chemotherapy. Bratlie (1942) and Buer \& Bratlie (1947) stated that aqueous solutions of trypaflavin and infusions of Indian ink were unevenly distributed in normal as well as abnormal glandular tissue, irrespective of whether they administered large or small amounts of liquid through the teat canal. Similar observations were made by Hovmand \& Overby (1955) in indurated glands after intramammary application of 1-2 I Indian ink infusions. Schipper (1955) investigated the dispersion of antibiotics infused into mammary glands both in ointment and in sterile distilled water $(500 \mathrm{ml})$, and found that the antibiotic contents in the dorsal third of the gland were much

*) Supported by a grant from Statens almindelige Videnskabsfond. 
smaller than the ventral third of the gland, both in the case of normal as well as infected glands.

Through autoradiographic studies with $\mathrm{S}^{35}$-penicillin, Ullberg, Hansson \& Funke (1958 b) found a fairly uniform distribution of both aqueous solutions and oil suspensions in normal mammary glands, whereas in the infected glands they found an uneven distribution (Ullberg et al. 1958 a; Funke 1961). By means of vegetable carbon dyes, McFarlane (1952) investigated the galactogenic dispersion and also found a very uneven distribution in the case of acute mastitis. By the addition of x-ray contrast compounds to an ointment base and to water, Hueber, Lofgrin, Reynolds \& Luther (1960) have shown an uneven distribution, when an ointment base was used as the vehicle for intramammary preparations.

Only a few papers have been published regarding the distribution of drugs in the mammary gland after treatment by oral or parenteral application. Ullberg (1954) demonstrated an even distribution of penicillin in the mammary gland of mice by autoradiographic technique, and Funke (1961) has also shown, by using the same method, that after parenteral application in goats penicillin was evenly distributed overall in the gland tissue both in normal as well as in acute and chronic mastitis cases; with the exception of tissues which are the site of necrosis and ischemia.

In this paper we shall give an account of a number of experiments on the distribution of sulphonamides in the udder tissues of cows after simultaneous intramammary and intravenous infusion. The dye, Food Green No. 4, is used as tracing material for the intramammary dispersion, and distribution of sulphonamides is demonstrated by colour reaction in situ as well as in vitro.

\section{METHODS}

The experiments were performed on 27 cows with normal lactating or non-lactating glands, as well as glands with different degrees of induration. After milking and stripping the cows were given sulphonamides by one of the following methods:

I a) intramammary application of 1 gram sulphadimidine in 4 grams vegetable oil with $50 \mathrm{mg}$ of Food Green No. 4 added. 
b) intramammary application of $40 \mathrm{ml}$ Supronal-emulsion $20 \%$ ad us. vet. ${ }^{\circledR}$ with $50 \mathrm{mg}$ Food Green No. 4 added.

II a) intramammary application of 4 grams vegetable oil containing $50 \mathrm{mg}$ Food Green No. 4 followed by intravenous infusion of injection of sulphadimidine sodium at a dose corresponding to $100 \mathrm{mg} / \mathrm{kg}$ bdw.

b) intramammary application of $40 \mathrm{ml}$ vehicle for Supronal emulsion $20 \%$ ad us vet. ${ }^{\circledR}$ containing $50 \mathrm{mg}$ Food Green No. 4 and intravenous infusion of Supronal solution $20 \%$ ad us. vet. ${ }^{\circledR}$, dose $100 \mathrm{mg} / \mathrm{kg}$ bdw.

1, 3 and 24 hours respectively after medication, blood samples were drawn, and the cows were sacrificed and the udders were removed. The udder halves were cut through and a colour photo was taken of the one half for documentation as to the dispersion of the dye, Food Green No. 4. Thereafter test for sulphonamide was carried out on the same cut surface, by spraying the following reagents on the surface: $50 \%$ trichloroacetic acid; 5 min. later a $2 \%$ sodium nitrite solution; 3 min. later again a $5 \%$ ammoniumsulphamate solution and, finally, after a 2 min. pause, a $2 \%$ aqueous solution of $\mathrm{N}$-(1-naphtyl)-ethylene-diamine dihydrochloride. The sulphonamides become apparent after this diazotization and coupling with redviolet colour. A further colour photo was taken of the cut surface after the colour development, for documentation of the sulphonamide distribution.

Pieces of tissue of approximately 40 grams were removed from the other half of the mammary glands, which were homogenized in an Ultra-Turrax. The contents of Food Green No. 4 were ascertained by suspending 20 grams homogenized tissue in $100 \mathrm{ml}$ distilled water. After shaking and centrifugation $5 \mathrm{ml}$ of the supernatant was added $10 \mathrm{ml}$ acetone. The mixture was placed in a refrigerator for approximately 16 hours, whereupon it was filtered and the clear filtrate was read in the Coleman spectrophotometer at $630 \mu$. The concentration was read on a standard curve worked out on a solution of Food Green No. 4

Supronal ${ }^{\circledR}$ consists of equal portions sulfamerazine (NFN) and sulfatolamide (NFN). The preparations were kindly placed at our disposal by A/G Bayer, Leverkusen, through A/S Akifarma, Copenhagen. 
in milk. The sulphonamide concentration in the same samples of gland tissues were determined according to Bratton \& Marshall's method (1939).

\section{RESULTS}

Distribution of sulphonamide and Food Green No. 4 after intramammary infusion.

From picture No. 1, which has been taken of the left half of an udder 24 hours after intramammary application of Supronal and Food Green No. 4, it is noted that the dye is evenly distributed in the left rear gland, apart from the most dorsal parts, whilst in the front quarter, both in a larger tissue area, dorso-caudal, and in smaller parts of the cisternal portion, there are completely uncoloured gland tissues. After sulphonamide reaction in situ, the same cut surface showed a distribution of sulphonamide which, as can be seen in picture No. 2, is identical with the spreading of Food Green No. 4. The gland was completely normal with regard to the milk ducts as well as the parenchyma and secretion. The similarity between the distribution of dye and sulphonamide as shown in the illustrations has been observed in all intramammary applications of sulphadimidine as well as Supronal.

This visually observed similarity in the distribution is also confirmed by quantitative chemical determinations of both the dye and sulphonamide in 48 pieces of tissue from 24 glands of cows. The cows were sacrificed 1, 3 and 24 hours respectively after intramammary application of dye, Food Green No. 4, combined with sulphadimidine or Supronal. The results of the analyses can be seen in table 1, which shows that where there was a low concentration of dye there was a corresponding low concentration of sulphonamides while a high concentration of dye in another sample from the same gland corresponded to a high concentration of sulphonamides. The table shows that the content of Food Green No. 4 and sulphonamide varies considerably from one area to another in the same udder. In most cases the cut surface through the gland showed clear lobar and lobular distribution of Food Green No. 4 and sulphonamide, as also shown in pictures 1 and 2. This lobular distribution causes small, completely uncoloured pieces of tissue to border directly up to highly coloured pieces of tissue. Therefore, in reality, the con- 
Table 1. The relation between the concentrations of Food Green No. 4 and sulphonamide in mammary gland tissue from 6 cows with normal and indurated glands. The cows were sacrificed 1, 3 and 24

hours after intramammary application of sulphadimidine and Supronal.

\begin{tabular}{|c|c|c|c|c|c|c|c|c|}
\hline & \multirow{2}{*}{\multicolumn{2}{|c|}{ Gland quarter }} & \multicolumn{2}{|c|}{$\begin{array}{l}\text { Cows sacrificed } \\
1 \text { hour after } \\
\text { application }\end{array}$} & \multicolumn{2}{|c|}{$\begin{array}{l}\text { Cows sacrificed } \\
3 \text { hours after } \\
\text { application }\end{array}$} & \multicolumn{2}{|c|}{$\begin{array}{l}\text { Cows sacrificed } \\
24 \text { hours after } \\
\text { application }\end{array}$} \\
\hline & & & $\begin{array}{c}\text { Food } \\
\text { Green } \\
\text { No. } 4 \\
\mu \mathrm{g} / \mathrm{g}\end{array}$ & $\begin{array}{c}\text { Sulphon- } \\
\text { amide } \\
\mu \mathrm{g} / \mathrm{g}\end{array}$ & $\begin{array}{c}\text { Food } \\
\text { Green } \\
\text { No. } 4 \\
\mu \mathrm{g} / \mathrm{g}\end{array}$ & $\begin{array}{c}\text { Sulphon- } \\
\text { amide } \\
\mu \mathrm{g} / \mathrm{g}\end{array}$ & $\begin{array}{c}\text { Food } \\
\text { Green } \\
\text { No. } 4 \\
\mu \mathrm{g} / \mathrm{g}\end{array}$ & 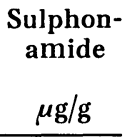 \\
\hline \multirow{8}{*}{$\begin{array}{l}\text { Sulphadimi- } \\
\text { dine }\end{array}$} & \multirow[t]{2}{*}{ l.f. } & dorsal & 1.7 & 81 & $<1$ & 19 & $\left.1.2^{\star}\right)$ & 12 \\
\hline & & ventral & 6.1 & 251 & 3.2 & 286 & $\left.12.0^{*}\right)$ & 12 \\
\hline & \multirow[t]{2}{*}{ I.r. } & dorsal & 0.7 & 26 & $<1$ & 370 & $<1$ & 14 \\
\hline & & ventral & 5.7 & 241 & 2.0 & 227 & $\left.12.4^{\star}\right)$ & 16 \\
\hline & \multirow[t]{2}{*}{ r.f. } & dorsal & $<1$ & 8 & $<1$ & 11 & $<1$ & 13 \\
\hline & & ventral & 1.6 & 66 & 1.5 & 77 & $\left.6.6^{*}\right)$ & 19 \\
\hline & \multirow[t]{2}{*}{ r.r. } & dorsal & $<1$ & 19 & $<1$ & 57 & 1 & 14 \\
\hline & & ventral & 2.0 & 159 & 2.1 & 222 & 2.6 & 15 \\
\hline \multirow[t]{8}{*}{ Supronal } & \multirow[t]{2}{*}{ l.f. } & dorsal & $\left.3.4^{\star}\right)$ & 1052 & $<1$ & 96 & $<$ & 222 \\
\hline & & ventral & $\left.2.6^{\star}\right)$ & 836 & 1.9 & 2947 & 4.0 & 1967 \\
\hline & \multirow[t]{2}{*}{ 1.r. } & dorsal & $\left.2.5^{\star}\right)$ & 975 & 1.2 & 1083 & 1 & 523 \\
\hline & & ventral & $\left.2.4^{\star}\right)$ & 578 & 0.9 & 7013 & 3.2 & 2935 \\
\hline & \multirow[t]{2}{*}{ r.f. } & dorsal & $\left.<1{ }^{*}\right)$ & 125 & 1.0 & 706 & 6.0 & 2572 \\
\hline & & ventral & $\left.1.2^{\star}\right)$ & 397 & 1.9 & 2576 & 16.7 & 3053 \\
\hline & \multirow[t]{2}{*}{ r.r. } & dorsal & $\left.2.3^{\star}\right)$ & 315 & $<1$ & 497 & 1.9 & 256 \\
\hline & & ventral & $\left.5.6^{\star}\right)$ & 544 & 1.2 & 3107 & 3.8 & 758 \\
\hline
\end{tabular}

*) Chronic indurative mastitis.

centration variations of Food Green No. 4 and sulphonamide can be greater than is shown in table 1, which gives the average concentration in the large tissue samples used for the analysis. The smallest concentrations of sulphonamide and Food Green No. 4 were most often measured in the central and dorsal parts of the glands. The uneven distribution of sulphonamide and Food Green No. 4 was observed both in normal glands and in glands with chronic indurative mastitis.

Table 1, also shows that the distribution is just as uneven after the use of $40 \mathrm{ml}$ Supronal as $4 \mathrm{ml}$ sulphadimidine preparation. However, the amount of Supronal used - 8 grams per gland - gives, in contrast to 1 gram sulphadimidine, a prolonged, relatively high sulphonamide concentration in the gland tissue.

24 hours after application, the distribution of Food Green 
No. 4 and Supronal are still uneven, whilst the distribution of sulphadimidine at this moment is completely uniform. This uniform distribution of sulphadimidine might be a result of absorption of the compound from the udder followed by secondary influx and distribution by the hematogenic route. This hypothesis is supported by the fact that the tissue concentration was approximately $70 \%$ of the blood plasma concentration $(20 \mu \mathrm{g} / \mathrm{ml})$ which corresponds to the distribution ratio after parenteral application of sulphadimidine, as is shown by the following experiments.

The distribution of sulphonamide after intravenous injection compared with the distribution of Food Green No. 4 by intramammary infusion.

As Food Green No. 4 in vehicles for intramammary application, can demonstrate the galactogenic distribution, it is possible to use this observation to illustrate the distribution of drugs, which are simultaneously introduced into the udder by hematogenic and galactogenic routes. 1, 3 and 24 hours respectively after simultaneous intramammary infusion of vehicles containing Food Green No. 4 and intravenous infusion of one of the injections containing sulphonamide, blood samples were taken from the jugular vein, and the cows were sacrificed. The mammary glands were removed and cut through. On the surface, the green colour directly demonstrated the galactogenic distribution, while after the sulphonamide reaction procedure a picture

P i cture 1. The distribution of the tracer dye, Food Green No. 4, in two normal glands 24 hours after intramammary infusion of Supronal-emulsion.

P i c t u r e 2. Same glands as in picture 1 after sulphonamide reaction in situ.

P i c ture 3. The distribution of Food Green No. 4 in two normal glands after intramammary infusion of the dye in vegetable oil.

$P$ i c t u r e 4. Same glands as in picture 3 after sulphonamide reaction. Sulphadimidine was injected intravenously 24 hours before sacrifice.

P i c ture 5. The distribution of Food Green No. 4 in a part of a gland with chronic indurative mastitis after intramammary infusion of the dye in vegetable oil.

Picture 6. The same part of gland as in picture 5 showing sulphonamide distribution one hour after intravenous injection of sulphadimidine. 
Folke Rasmussen: Distribution of Sulphonamides in the Mammary Gland.

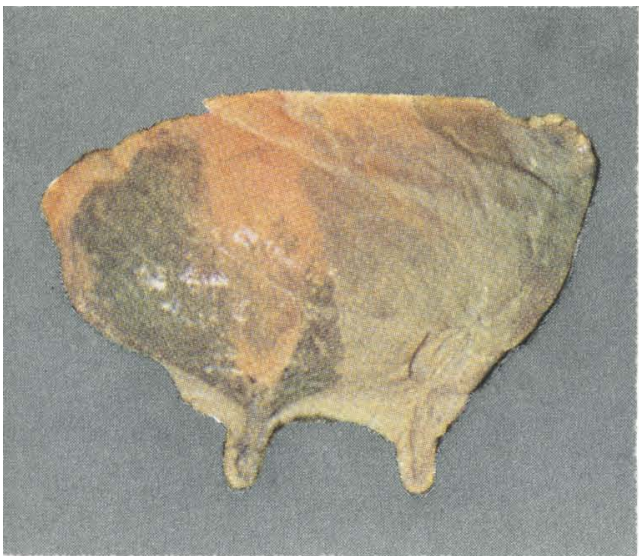

1

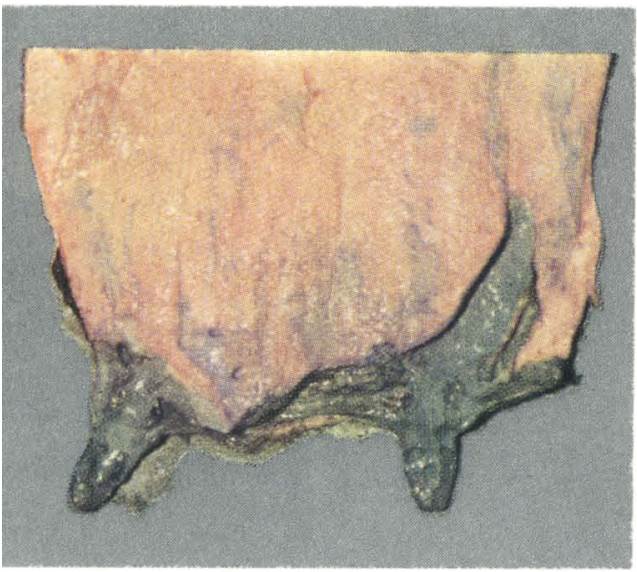

3

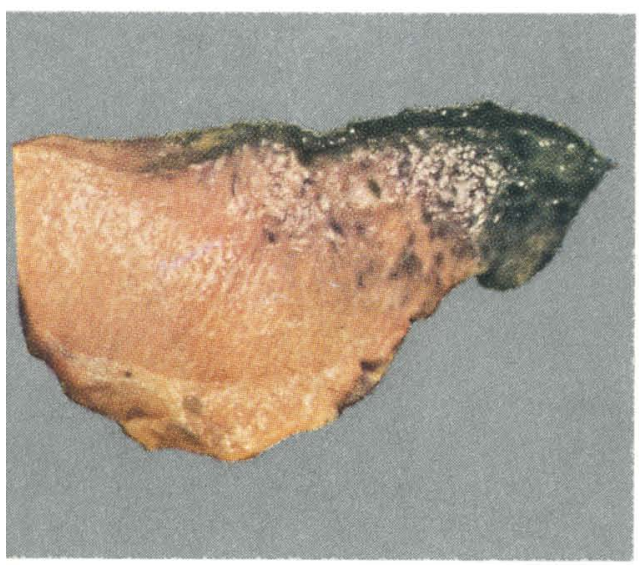

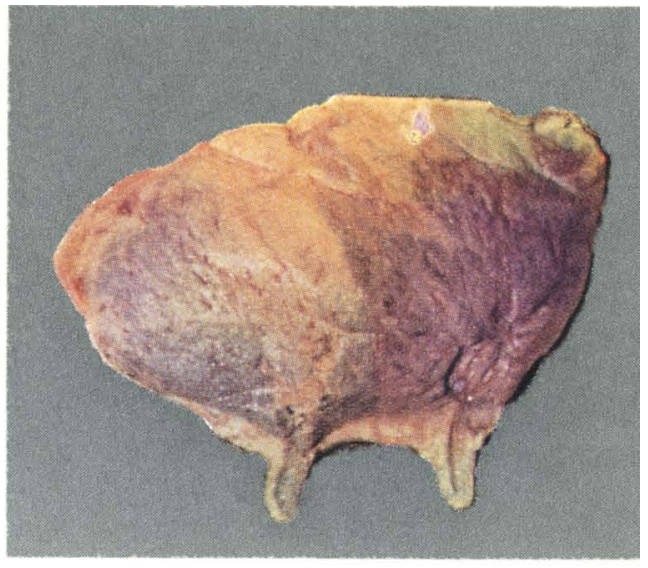

2

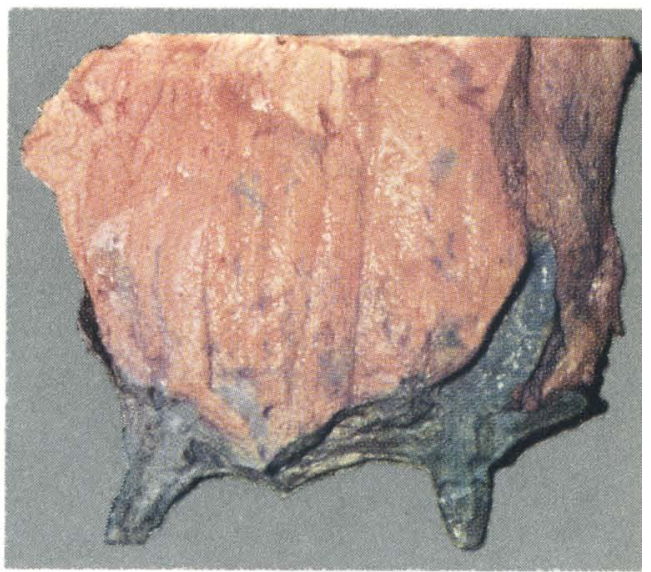

4

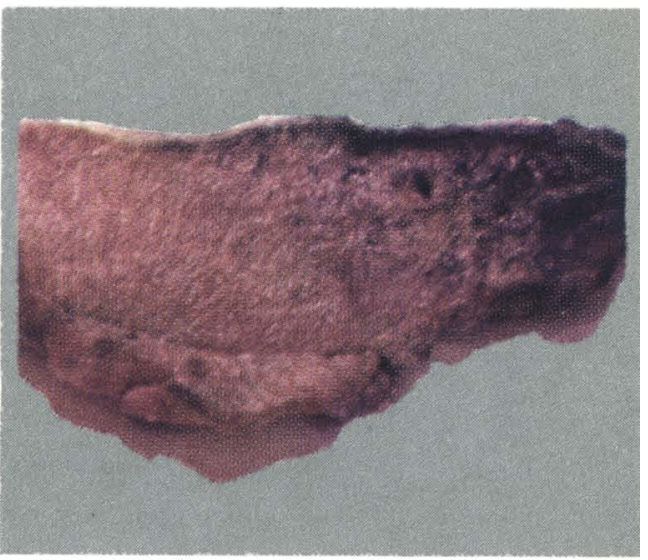


was obtained of the distribution due to the systemic treatment. Pictures 3 and 4 illustrate the distribution in a normal udderhalf of a cow which has calved several times. The cow was sacrificed 24 hours after the injections. The picture shows that the green colour introduced by intramammary infusion was distributed very unevenly, while the red violet colour of the sulphonamide reaction (picture 4) shows that the sulphadimidine administered intravenously was evenly distributed in the glands.

In the same way, pictures 5 and 6 show the distribution of the dye introduced by intramammary infusion, and sulphonamide administered parenterally, in a part of a gland with chronic indurative changes. The gland was removed 1 hour after administration of sulphonamide. The distribution in the mammary gland with such pronounced indurative changes are extremely uneven after intramammary infusion, but completely uniform after parenteral application.

In order to illustrate the quantitative distribution of Food Green No. 4 and sulphonamide in the mammary gland tissue, samples of tissue were taken from all the mammary glands examined, for the purpose of analysing the contents of dye and sulphonamide. The results of the analyses of tissue samples from 3 normal or only slightly indurated udders can be seen in table 2 .

T a b l e 2. The concentrations of Food Green No. 4 and sulphonamide in blood plasma and mammary gland tissue 1, 3 and 24 hours after intramammary application of Food Green No. 4 and intravenous infusion of sulphadimidine in 3 cows.

\begin{tabular}{|c|c|c|c|c|c|c|c|}
\hline \multirow[t]{2}{*}{$\begin{array}{l}\text { Gland } \\
\text { quarter }\end{array}$} & \multirow[t]{2}{*}{ Sample } & \multicolumn{2}{|c|}{$\begin{array}{l}\text { Sacrificed } 1 \text { hour } \\
\text { after application }\end{array}$} & \multicolumn{2}{|c|}{$\begin{array}{l}\text { Sacrificed } 3 \text { hours } \\
\text { after application }\end{array}$} & \multicolumn{2}{|c|}{$\begin{array}{l}\text { Sacrificed } 24 \text { hours } \\
\text { after application }\end{array}$} \\
\hline & & $\begin{array}{l}\text { Food } \\
\text { reen No. } 4 \\
\mu \mathrm{g} / \mathrm{g}\end{array}$ & $\begin{array}{l}\text { Sulphon- } \\
\text { amide } \\
\mu \mathrm{g} / \mathrm{g}\end{array}$ & $\begin{array}{c}\text { Food } \\
\text { Green No. } 4 \\
\mu \mathrm{g} / \mathrm{g}\end{array}$ & $\begin{array}{l}\text { Sulphon- } \\
\text { amide } \\
\mu \mathrm{g} / \mathrm{g}\end{array}$ & $\begin{array}{c}\text { Food } \\
\text { Green No. } 4 \\
\mu \mathrm{g} / \mathrm{g}\end{array}$ & $\begin{array}{c}\text { Sulphon- } \\
\text { amide } \\
\mu \mathrm{g} / \mathrm{g}\end{array}$ \\
\hline & $\begin{array}{l}\text { blood plasma } \\
\mu \mathrm{g} / \mathrm{ml}\end{array}$ & - & 188 & - & 166 & - & 62 \\
\hline \multirow[t]{2}{*}{ l.f. } & dorsal & 3.5 & 146 & 2.1 & 141 & 4.6 & 50 \\
\hline & ventral & 4.5 & 140 & 2.3 & 163 & 4.8 & 52 \\
\hline \multirow[t]{2}{*}{ l.r. } & dorsal & 3.0 & 133 & 2.1 & 195 & 1.0 & 50 \\
\hline & ventral & 3.0 & 140 & 6.0 & 164 & 4.2 & 47 \\
\hline \multirow[t]{2}{*}{ r.f. } & dorsal & 4.5 & 148 & 1.9 & 133 & 2.4 & 46 \\
\hline & ventral & 2.4 & 150 & 11.9 & 151 & 5.0 & 47 \\
\hline \multirow[t]{2}{*}{ r.r. } & dorsal & 5.2 & 145 & 1.8 & 133 & 0.9 & 49 \\
\hline & ventral & 2.2 & 140 & 4.4 & 143 & 3.7 & 47 \\
\hline
\end{tabular}


T a b l e 3. The concentrations of Food Green No. 4 in the mammary gland tissue after intramammary application are listed together with the concentrations of sulphonamide given intravenously at the same time. (Inject. sulphadimidin. $100 \mathrm{mg} / \mathrm{kg}$ bdw.).

\begin{tabular}{|c|c|c|c|c|c|c|c|}
\hline \multirow{2}{*}{$\begin{array}{l}\text { Sacrificed } \\
\text { hours after } \\
\text { application }\end{array}$} & \multirow{2}{*}{$\begin{array}{c}\text { Number } \\
\text { of } \\
\text { glands }\end{array}$} & \multirow{2}{*}{$\begin{array}{l}\text { Number } \\
\text { of pieces } \\
\text { of gland } \\
\text { tissue }\end{array}$} & \multirow{2}{*}{$\begin{array}{c}\text { Food Green } \\
\text { No. } 4 \\
\text { min.-max. } \\
\mu \mathrm{g} / \mathrm{g}\end{array}$} & \multicolumn{2}{|c|}{ Sulphonamide } & \multirow{2}{*}{$\begin{array}{c}\text { Blood } \\
\text { plasma } \\
\text { sulphon- } \\
\text { amide } \\
\mu \mathrm{g} / \mathrm{ml}\end{array}$} & \multirow[b]{2}{*}{ Diagnosis } \\
\hline & & & & $\begin{array}{c}\min .-\max . \\
\mu \mathrm{g} / \mathrm{g}\end{array}$ & $\begin{array}{r}\text { average } \\
\mu \mathrm{g} / \mathrm{g}\end{array}$ & & \\
\hline 1 & 2 & 3 & $<1-17$ & $125-149$ & 136 & 172 & $\begin{array}{l}\text { Chronic indurative and } \\
\text { purulent mastitis. }\end{array}$ \\
\hline 1 & 4 & 8 & $2-5$ & $133-150$ & 143 & 188 & Slightly indurative mastit: \\
\hline 1 & 2 & 4 & $<1-7$ & $119-140$ & 130 & 174 & $\begin{array}{l}\text { Right rear chronic indur } \\
\text { tive mastitis, other glan } \\
\text { normal lactating. }\end{array}$ \\
\hline 1 & 4 & 8 & $<1-8$ & $187-237$ & 215 & 241 & Normal lactating. \\
\hline 3 & 3 & 6 & $<1-6$ & $77-97$ & 85 & 169 & $\begin{array}{l}\text { Right front chronic indur } \\
\text { tive mastitis, other glan } \\
\text { slightly indurated. }\end{array}$ \\
\hline 3 & 3 & 5 & $<1-4$ & $92-109$ & 103 & 179 & Normal lactating. \\
\hline 3 & 2 & 5 & $3-5$ & $110-115$ & 112 & 162 & Slightly indurative mastit \\
\hline 3 & 4 & 8 & $2-12$ & $133-195$ & 153 & 166 & $\begin{array}{l}\text { Dry, left front and rear } \\
\text { slightly indurated. }\end{array}$ \\
\hline 24 & 2 & 3 & $3-14$ & $39-44$ & 41 & 78 & Normal lactating. \\
\hline 24 & 4 & 8 & $<1-4$ & $48-59$ & 53 & 79 & Normal dry. \\
\hline 24 & 4 & 8 & $<1-5$ & $46-52$ & 48 & 62 & Normal lactating. \\
\hline 24 & 4 & 8 & $<1-10$ & $26-37$ & 33 & 54 & Normal dry. \\
\hline
\end{tabular}

The table shows that the concentrations of sulphonamide in the 8 examined tissue samples from the same udder were very uniform. With the exception of one tissue sample the concentrations were not so high as the concentrations in the blood plasma determined at the same time. On the other hand, the contents of the galactogenically dispersed Food Green No. 4 varies in the same tissue samples.

This type of experiment was performed on 21 cows in all. As the concentrations of sulphonamide in the tissue samples in all cases were more or less uniform, only the minimum and maximum values for the content of sulphonamide and dye in the tissue samples from the same udder are stated in tables 3 and 4 .

Table 3 shows the results after intravenous application of 
T a b l e 4. The concentrations of Food Green No. 4 in the mammary gland tissue after intramammary application are listed together with the concentrations of sulphonamide given intravenously at the same time. (Supronal ${ }^{\circledR}$ ad us. vet. $100 \mathrm{mg} / \mathrm{kg}$ bdw.).

\begin{tabular}{|c|c|c|c|c|c|c|c|}
\hline \multirow{2}{*}{$\begin{array}{l}\text { crificed } \\
\text { urs after } \\
\text { plication }\end{array}$} & \multirow{2}{*}{$\begin{array}{c}\text { Number } \\
\text { of } \\
\text { glands }\end{array}$} & \multirow{2}{*}{$\begin{array}{l}\text { Number } \\
\text { of pieces } \\
\text { of gland } \\
\text { tissue }\end{array}$} & \multirow{2}{*}{$\begin{array}{c}\text { Food Green } \\
\text { No. } 4 \\
\text { min. }- \text { max. } \\
\mu \mathrm{g} / \mathrm{g}\end{array}$} & \multicolumn{2}{|c|}{ Sulphonamide } & \multirow{2}{*}{$\begin{array}{l}\text { Blood } \\
\text { plasma } \\
\text { sulphon- } \\
\text { amide } \\
\mu \mathrm{g} / \mathrm{ml}\end{array}$} & \multirow[b]{2}{*}{ Diagnosis } \\
\hline & & & & $\begin{array}{c}\min .-\max . \\
\mu \mathrm{g} / \mathrm{g}\end{array}$ & $\begin{array}{c}\text { average } \\
\mu \mathrm{g} / \mathrm{g}\end{array}$ & & \\
\hline 1 & 4 & 8 & $<1-2$ & $50-106$ & 78 & 156 & Normal lactating. \\
\hline 1 & 4 & 8 & $2-23$ & $62-107$ & 80 & 160 & Dry, slightly indurated. \\
\hline 1 & 4 & 8 & $<1-32$ & $54-122$ & 89 & 127 & Normal lactating. \\
\hline 3 & 4 & 8 & $<1-3$ & $37-59$ & 47 & 76 & Normal lactating. \\
\hline 3 & 4 & 8 & $<1-12$ & $50-94$ & 76 & 168 & Chronic indurative mastitis. \\
\hline 3 & 4 & 8 & $<1-2$ & $39-54$ & 47 & 96 & Dry, slightly indurated. \\
\hline 24 & 4 & 8 & $1-11$ & $8-11$ & 9 & 12 & Normal lactating. \\
\hline 24 & 4 & 8 & $<1-5$ & $10-15$ & 12 & 28 & Normal lactating. \\
\hline 24 & 4 & 8 & $<1-3$ & $6-9$ & 7 & 9 & $\begin{array}{l}\text { Slightly indurated, left } \\
\text { front acute mastitis. }\end{array}$ \\
\hline
\end{tabular}

sulphadimidine. It can be seen that sulphadimidine is distributed very evenly everywhere in the gland tissue - both in the normal and in the indurated tissue. In the same samples of gland tissue the distribution of the tracer colour introduced by intramammary infusion shows very great variations. During the course of the mentioned 24 hours, the concentration of sulphonamide both in the mammary gland tissue and in the blood plasma decreases, and on an average the concentration of sulphonamide in the mammary gland tissue is $50-90 \%$ of that of the blood plasma.

The distribution of sulphonamide in the mammary gland tissue after intravenous injection of Supronal is also compared with the distribution of the tracer colour in the vehicle for Supronal emulsion given as an intramammary infusion. The results of these experiments can be seen in table 4, which shows that the sulphonamide, in these cases also, are distributed quite uniformly in the gland tissue, while the locally applied tracer colour is unevenly distributed. Variations in the concentration of sulphonamide in the gland tissue from the same udder especially one hour after the application - are somewhat greater after the use of Supronal than after sulphadimidine. The concentration of sulphonamide in the mammary gland tissue comprised $50-80 \%$ of that in the blood plasma. 


\section{DISCUSSION}

As previous experiments have shown that the food colour, Food Green No. 4 (New C.I. 42090), introduced by intramammary infusion, can be used for direct visual demonstration of penicillin residues in milk (Dalgaard-Mikkelsen \& Rasmussen 1957; Rasmussen \& Simesen 1960; Høgh \& Rasmussen 1961), it seemed logical to determine whether this same triphenylmethane dye could also be used in the study of the distribution of drugs in the mammary gland tissue. The experiments presented have shown that the tracer dye can reflect, in a satisfactory manner, the distribution of sulphonamides in the udder after intramammary infusion, and it has been shown that dye as well as sulphonamide suspensions are distributed uneven both in normal and in indurated mammary glands. Therefore, the results are in agreement with the results which, among others, have been demonstrated by Bratlie (1942), Buer \& Bratlie (1947), McFarlane (1952) and Grafe (1961), using other tracer dyes, Hueber et al. (1960) using intramammary applications of x-ray contrast compounds, and Schipper (1955) and Leidl (1963) by direct antibiotic determinations on tissue samples. Likewise, there are conformaties in the results of autoradiographic studies on the distribution of $\mathrm{S}^{35}$-penicillin in inflammed mammary glands of cows and goats (Ullberg et al. 1958 a; Funke 1961), while the latter authors found a fairly uniform distribution in normal mammary glands of goats.

In the treatment of acute mastitis, where swelling of the interstitium and closure of the smaller milk ducts or blockage of these ducts by inflammatory products is present (vide Spencer \& McNutt 1950; McFarlane 1952; Diernhofer 1955; Ullberg et al. 1958 a; Funke 1961) the local intramammary application with the apparent small possibilities of galactogenic distribution must be considered less rational than systemic treatment, which is also recommended by a.o., Pattison (1958), Funke (1961) and Wilson (1961), especially in the case of staphylococcal mastitis.

In the case of chronic indurative mastitis, where proliferations, granulations and fibrous tissue (vide Pattison 1951, 1952, 1958; Helmboldt, Jungherr \& Plastridge 1953; Pattison \& Smith 1953; Derbyshire 1958; Ullberg et al. 1958 a; Funke 1961; Renk 1961; Platonow \& Blobel 1963) can block the distribution via the milk ducts, the intramammary application must in many cases by considered as inadequate. Even in cases of slight infections, 
without marked pathological tissue changes, the galactogenic dispersion of intramammary injections - according to the observations presented here on normal glands - does not give any assurance of the attainment of adequate concentrations everywhere in the gland tissue. Therefore recurrences and development of resistance of the invading microorganisms have to be expected.

By using very large doses one can, to a certain degree, compensate for the uneven distribution resulting from intramammary infusion. This seems to be apparent from the result by infusion of 8 grams Supronal per gland. However, it must be remembered that the concentration in the $\mathbf{4 0}$ gram large tissue sample examined, could have concealed differences in the lobular distribution, which are larger than those shown in table 1.

In order to improve the distribution of intramammary infusions Vigue (1959) a. o., added polyoxyethylene sorbitan monoleate (polysorbate 80) which, by reducing the surface tension should give a better distribution of the ointment and oily bases in the mammary glands. However, H $\phi g h$ \& Rasmussen (1965) have found that while intramammary injections containing polysorbate 80 are distributed evenly in the secreted milk, the distribution is not uniform within the glandular tissue.

After intravenous injections of sulphonamide a uniform distribution has been observed both in normal glands and in tissue with pathological changes. A similar uniform distribution in the mammary gland has been demonstrated by Funke (1961) after parenteral application of $\mathbf{S}^{35}$-penicillin to goats. Only in cases of serious changes of the blood supply the hematogenic route will fail. For drugs with acid properties the concentration which is attained in the parenchyma is, as in milk (Rasmussen 1958, 1959), less than, but directly proportional to the concentration in blood plasma, as a consequence of the diffusion of the nonprotein-bound non-ionized fraction.

After intramammary application of drugs these might be absorbed from the mammary gland (Murnane 1945; Jepsen 1950; Funke 1961; Rasmussen 1962). Absorption has also been demonstrated in these experiments, as blood samples drawn from the jugular vein after intramammary application of sulphadimidine and Supronal, contained sulphonamide. The concentration of sulphadimidine in blood plasma, 24 hours after intramammary infusion was $20 \mu \mathrm{g} / \mathrm{ml}$ and in gland tissue $12-19 \mu \mathrm{g} / \mathrm{g}$. This can 
be taken as a manifestation that the locally applied sulphonamide has been absorbed from the mammary gland and thereupon by the vascular route transported to the organ.

\section{REFERENCES}

Bratlie, $O .:$ Verdien av kjemoterapien ved mastitis. Norsk Vet. Tidskr. 1942, 54, 355-386.

Bratton, A. C. \& E. K. Marshall: A new coupling component for sulfanilamide determination. J. Biol. Chem. 1939, 128, 537-550.

Buer, A. W. \& O. Bratlie: Fordelingen av infusjonsvesken i juret. Skand. Vet. Tidskr. 1947, 37, 565-596.

Dalgaard-Mikkelsen, S. \& Folke Rasmussen: R $\varnothing$ befarve i antibiotikaholdige intramammaria. Nord. Vet.-Med. 1957, 9, 852-854.

Derbyshire, J. B.: The pathology of experimental staphylococcal mastitis in the goat. J. Comp. Path. 1958, 68, 449-454.

Diernhofer, K.: Epithel- und andere Gewebsschranken in der Chemotherapie. Wien. tierärztl. Mschr. 1955, 42, 775-782.

Funke, $H .:$ The distribution of $S^{35}$-labelled benzylpenicillin in normal and mastitic mammary glands of cows and goats after local and systemic administration. Acta vet. scand. 1961, 2, suppl. 1.

Grafe, Sylvia: Vergleichende "Entamid"-Bestimmungen im Blut und in der Milch von Rindern unter besonderer Berücksichtigung des Milchspiegels und Versuche zur Erhöhung des "Entamid"Milchspiegels durch das Angiolytikum "Vasculat". Diss. Berlin. 1961, p. 46.

Helmboldt, C. F., E. L. Jungherr \& W. N. Plastridge: The histopathology of bovine mastitis. Storrs Agric. Exp. Sta. 1953, Bull. 305, 3-90.

Hovmand, H. C. \& A. J. Overby: Bakteriologisk effekt og udskillelse af dipenicillin og "Leocillin" efter intramuskulær behandling. Medlemsbl. Danske Dyrlægeforening 1955, 38, 519_523.

Hueber, W. G., G. E. Lofgrin, W. Reynolds \& H. G. Luther: Vehicles for intramammary mastitis preparations. Vet. Med. 1960, 55, 35-38.

Høgh, P.\& Folke Rasmussen: Tracer dye Green S (Food Green No. 4) in penicillin preparations for intramammary application, II. Acta vet. scand. 1961, 2, 185-197.

Høgh, P.\& Folke Rasmussen: The distribution of penicillin and Food Green No. 4 in the mammary glands of cows. To be published 1965.

Jepsen, Aage: Penicillinterapi mod yverinfektioner. Unders $\varnothing$ gelser over penicillinets elimination og resorption efter intramammær applikation. Nord. Vet.-Med. 1950, 2, 447-480.

Leidl, W.: Beitrag zur Therapie der Mastitiden, Vortrag 1963, zit. W. Gedek et al.: Zum Vorkommen antibiotikaresistenter Stämme der Familie Micrococcaceae in Kuhmilch. Tierärztl. Umschau 1964, 19, 337-340. 
McFarlane, D.: As cited by $C$. W. Turner: The mammary gland. Lucas Brothers, Columbia 1952, p. 163.

Murnane, D.: A preliminary report on the treatment of clinical and subclinical streptococcal and staphylococcal infections of the bovine udder with penicillin. Aust. Vet. J. 1945, 21, 82-90.

Pattison, I. H.: Studies on experimental streptococcal mastitis. J. Comp. Path. 1951, 61, 71-85.

Pattison, I. H.: Studies on experimental streptococcal mastitis. J. Comp. Path. 1952, 62, $1-5$.

Pattison, I. H.: The progressive pathology of bacterial mastitis. Vet. Rec. 1958, 70, 114-117.

Pattison, I. H. \& I. M. Smith: The histology of experimental Streptococcus Dysgalactiae mastitis in goats. J. Path. Bact. 1953, 66, $247-250$.

Platonow, I. \& H. Blobel: Therapeutic failures in chronic staphylococcic mastitis. J. Amer. Vet. Med. Ass. 1963, 142, 1097-1101.

Rasmussen, Folke: Mammary excretion of sulphonamides. Acta pharmacol. et toxicol. 1958, 15, 139-148.

Rasmussen, Folke: Mammary excretion of benzylpenicillin, erythromycin, and penethamate hydroiodide. Acta pharmacol. et toxicol. 1959, 16, 194-200.

Rasmussen, Folke: Absorption af lægemidler fra mælkekirtelen. 9th Nordic Veterinary Congress, Copenhagen 1962, 695-699.

Rasmussen, Folke \& Birgitte Simesen: Tracer dye Green $\mathrm{S}$ in penicillin preparations for intramammary application. Nord. Vet.-Med. 1960, 12, 120-132.

Renk, W.: Pathogenese der durch Staphylokokken hervorgerufenen Euterentzündungen. Berl. Münch. Tierärztl. Wschr. 1961, 74, 1-4.

Schipper, I. A.: Comparison of vehicles in intramammary therapy of bovine mastitis. Vet. Med. 1955, 50, 111-113.

Spencer, G. R. \& S. H. McNutt: Pathogenesis of bovine mastitis. Amer. J. Vet. Res. 1950, 11, 188-198.

Ullberg, S.: Studies on the distribution and fate of $S^{35}$-labelled benzylpenicillin in the body. Acta Radiol. 1954, suppl. 118.

Ullberg, S., E. Hansson \& H. Funke: Distribution of penicillin in mastitic udders following intramammary injection - an autoradiographic study. Amer. J. Vet. Res. 1958 a, 19, 84-92.

Ullberg, S., E. Hansson \& H. Funke: Distribution of aqueous penicillin and penicillin in oil in normal goat udders following intramammary injection - an autoradiographic study. Amer. J. Vet. Res. 1958 b, 19, 135-138.

Wilson, C. D.: The treatment of staphylococcal mastitis. Vet. Rec. 1961, 73, $1019-1024$.

Vigue, $R$. F.: Practical mastitis infusion additive. Vet. Med. 1959, 54, $67-69$. 


\section{SUMMARY}

In experiments on cows it has been shown that addition of the tracer dye, Food Green No. 4, to intramammary preparations containing sulphonamide by inspection of cut surfaces directly demonstrates the galactogenic dispersion. By sulphonamide reaction on the cut surface of the udder and quantitative chemical determinations of both the dye and sulphonamide on pieces of gland tissue an identical distribution of the two components has been found. In normal as well as in glands with chronic indurative mastitis an uneven distribution after intramammary infusion has been found.

After simultaneous intramammary application of vehicles for sulphonamide intramammary injections containing Food Green No. 4 and intravenous injection of sulphonamide, an uneven distribution of the intramammary preparation but an uniform distribution of the parenterally injected sulphonamide was demonstrated.

The results obtained are discussed in relation to the treatment of mastitis in cows and it is concluded that the blockage of the galactogenic dispersion of intramammary infusions by the pathological changes in acute as well as chronic mastitis, indicate systemic treatment with distribution of the drugs by the vascular route.

\section{ZUSAMMENFASSUNG}

Verteilung von Sulfonamiden in der Milchdrüse bei Kühen nach intramammärer und intravenöser Applikation.

In Versuchen an Kühen ist es gezeigt, dass es bei Zusatz der Anzeigefarbe, Food Green No. 4, an sulfonamidhaltigen Intramammaria möglich ist, durch Inspektion der Schnittfäche der Milchdrüse einen direkten scheinbaren Ausdruck der galaktogenen Verteilung des Arzneimittels zu erreichen. Mittels Sulfonamidreaktions auf der Schnittfläche und chemischer Analysen an Proben der Milchdrüse sind eine identische, ungleichmässige Verteilung der Anzeigefarbe und des Sulfonamids gezeigt worden. Die ungleichmässige Verteilung war sowohl in normalen als indurierten Milchdrüsen nach intramammären Infusionen zu finden.

Nach gleichzeitiger intramammärer Applikation von Vehikeln für sulfonamidhaltige Intramammaria mit Zusatz von Food Green No. 4 und intravenöser Infusion von Sulfonamid wird eine ungleichmässige Verteilung des intramammär applizierten gefunden, dagegen wird eine gleichmässige Verteilung des parenteral zugeführten Sulfonamids erreicht.

Die erzielten Resultate werden im Hinblick auf die Behandlung von Mastitis bei Kühen diskutiert. Es wird konkludiert dass die Hindernisse der galaktogenen Ausbreitung von intramammär zugeführten Arzneimitteln, die auf den pathologischen Veränderungen sowohl bei akuter als bei chronischer Mastitis beruhen, die Zufuhr von Arzneimitteln auf hämatogenem Weg zum Euter nach oraler oder parenteraler Behandlung indizieren. 


\section{SAMMENDRAG}

Fordeling af sulfonamider $i$ mælkekirtelen hos køer efter intramammær og intraven $\varnothing$ s applikation.

I fors $\varnothing \mathrm{g}$ på kфer er det vist, at der ved tilsætning af røbefarven, Food Green No. 4, til sulfonamidholdige intramammaria kan opnås et direkte synligt udtryk for den galaktogene udbredelse af lægemidlet ved inspektion af yverets snitflade. Ved sulfonamidreaktion udf $\varnothing \mathrm{rt}$ på snitfladen samt ved kemiske analyser på udtagne vævsprøver er der påvist en identisk, uensartet fordeling af røbefarve og sulfonamid, såvel i normale som indurerede kirtler efter intramammær infusion.

Efter samtidig intramammær applikation af vehikler for sulfonamidholdige intramammaria tilsat Food Green No. 4 og intraven $\varnothing \mathrm{s}$ infusion af sulfonamid fås en uensartet fordeling af det intramammært applicerede, medens der er påvist en ensartet fordeling af det parenteralt tilf $\varnothing$ rte sulfonamid.

De opnåede resultater diskuteres i relation til behandling af mastitis hos køer, og det konkluderes, at de hindringer af den galaktogene udbredelse af intramammært tilførte lægemidler, som beror på patologiske forandringer ved såvel akutte som kroniske mastiter, indicerer tilførsel af lægemiddel ad hæmatogen vej til yveret ved universel behandling.

(Received January 31, 1964). 